\title{
Gonorrhoea Caused by A Mixture of Penicillinase-Positive and -Negative Gonococci : A Case Report
}

\author{
Shin-ichi Yoshida', Shinji URABE ${ }^{2}$ and Yasuo MizUGuchI ${ }^{1}$ \\ 'Department of Microbiology, School of Medicine, University of Occupational and \\ Environmental Health, Japan. Kitakyushu 807, Japan \\ ${ }^{2}$ Urabe Hospital. Nishi-nakasu, Fukuoka 810, Japan
}

\begin{abstract}
A 23-year-old unmarried man was infected with gonorrhoea from a prostitute in Fukuoka City and was treated with ampicillin which resulted in failure. By a rapid iodometric test it was found that the isolates before the treatment were penicillinase-negative. After the ampicillin treatment, however, the isolates turned to penicillinase-positive but were, in fact, a mixture of penicillinase-positive and penicillinase-negative gonococcal strains. Treatment by spectinomycin and doxycycline resulted in failure but the gonorrhoea was cured by ribostamycin.
\end{abstract}

Key words: gonorrhoea, penicillinase-producing Neisseria gonorrhoeae, mixed infection.

(Received 8 November 1983)

\section{Introduction}

Penicillinase-producing Neisseria gonorrhoeae (PPNG) strains have been found in many countries throughout the world (Perine et al., 1979; Center for Disease Control, 1982). In Fukuoka, Japan, the incidence of PPNG strains was approximately $15 \%$ in 1981 (Yoshida et al., 1982; Urabe et al., 1983). It has been reported by some investigators that among gonorrhoea caused by PPNG strains, there are cases caused by a mixture of PPNG and non-PPNG strains although the ratio of such cases is low (Percival et al., 1976 ; Nayyar et al., 1980; Chowdhury et al., 1981). We report here such a case who at first discharged non-PPNG but discharged both PPNG and non-PPNG strains after being treated with ampicillin.

\section{Case Report}

Clinical features and treatment

A 23-year-old unmarried man was admitted because of urethral discharge. Four days before the admission he had sexual contact with a prostitute in Fukuoka City. A Gram-stained smear of urethral discharge showed many intracellular Gram-negative diplococci. Under a diagnosis of gonorrhoea, he was treated with $1.5 \mathrm{~g}$ of ampicillin orally per day for four days. After a 4-day treatment, however, symptom did not change so the administration of ampicillin was extended 3 more days. In the meantime the 
Table 1. Minimum inhibitory concentration (MIC) of antibiotics for isolates

\begin{tabular}{clcccccc}
\hline \multirow{2}{*}{$\begin{array}{c}\text { Date of } \\
\text { isolation }\end{array}$} & \multicolumn{7}{c}{ MIC $(\mu \mathrm{g} / \mathrm{ml})$} \\
\cline { 3 - 7 } & Isolates & PcG & AMPC & DOTC & SP & MINO & CZX \\
\hline 22 Nov. & Primary culture & 0.10 & 0.20 & 0.39 & 25 & 0.78 \\
29 Nov. & Primary culture & 12.5 & 50 & 3.13 & 25 & 1.56 & 0.025 \\
& PPNG & 25 & 50 & 3.13 & 25 & 0.025 \\
& non- PPNG & 1.56 & 0.78 & 3.13 & 25 & \multirow{2}{*}{13} & 25 \\
\hline
\end{tabular}

PcG: penicillin G, AMPC :moxicillin, DOTC : doxycycline,

$\mathrm{SP}$ : spectinomycin, MINO : minocycline, CZX : ceftizoxime.

pathogen isolated by the first medical examination was identified as Neisseria gonorrhoeae and by a rapid iodometric test (World Health Organization, 1976) its penicillinase production was found to be negative. After the 7-day therapy there was no clinical improvement, so treatment was changed to an intramuscular injection of $2.0 \mathrm{~g}$ of spectinomycin. The gonococci isolated on the 7th day were penicillinase-positive and the infection was shown to be due to a mixture of penicillinase-positive and penicillinasenegative strains. The spectinomycin treatment decreased the urethral discharge but the symptom recurred 4 days later. Doxycycline $200 \mathrm{mg}$ per day was administered for three days but this treatment did not change the symptom. The gonorrhoea was cured at last by a daily shot of $1.0 \mathrm{~g}$ of ribostamycin intramuscularly over a period of 5 days. The patient denied any reinfection from the time of the first medical examination.

Minimum inhibitory concentrations of the isolates

Antibiotic susceptibility was determined by the agar dilution method for each isolate (Table 1). First isolates (22 Nov.) were fairly sensitive to penicillin G (PcG) and amoxicillin (AMPC). But after treatment by ampicillin for 7 days, the second isolates (29 Nov.) showed very high resistance to PcG and AMPG. The isolates, in fact, were a mixture of PPNG and non-PPNG strains. MICs of PcG for PPNG or non-PPNG strains were 25 $\mu \mathrm{g} / \mathrm{ml}$ or $1.56 \mu \mathrm{g} / \mathrm{ml}$, respectively. The third isolate $(10 \mathrm{Dec}$.), two days after the treatment by spectinomycin, showed very high resistance to PcG and AMPG and produced penicillinase. All isolates were sensitive to spectinomycin in vitro although treatment by spectinomycin resulted in failure.

\section{Discussion}

By a rapid iodometric test the gonococcus isolated from the primary culture did not show penicillinase production. The test became positive after a 7-day ampicillin therapy. The patient denied reinfection during this period. It appears likely that small numbers of PPNG mixed at first with large numbers of non-PPNG became predominant through the ampicillin therapy. 
It has been reported that PPNG strains have 4.7 or $3.4 \mathrm{Mdal}$ penicillinase-producing plasmid and 24.5 Mdal transfer plasmid (Sparling et al., 1981). We examined the plasmid profile and confirmed that PPNG strains isolated from this patient had 4.7 and 24.5 Mdal plasmid (data not shown).

Bae et al. (1983) have reported a reagent-impregnated filter paper replica method to detect $\beta$-lactamase production on agar plates. By this method, mixed infection by PPNG and non-PPNG strains are easily found on the primary culture.

Mixed infection or polymicrobial infection is common in routine bacterial infection. Therefore practitioners for sexually transmitted diseases should pay close attention to gonorrhoea caused by a mixture of PPNG and non-PPNG strains, even if tests for penicillinase production are negative on the primary culture.

\section{References}

Bae, B. H., Ledesma, G. \& Korzis, J. (1983) : Analysis of Neisseria gonorrhoeae for in situ $\beta$-lactamase production by reagent-impregnated filter paper replica methods. J. Clin. Microbiol., 17: 545-547.

Center for Disease Control (1982): Global distribution of penicillinase-producing Neisseria gonorrhoeae (PPNG). Morbid. Mortal. Weekly Rep., 31: 1-3.

Chowdhury, M. N. H., Pareek, S. S. \& Mahgoub, E-S. (1981) : Penicillinase-producing Neisseria gonorrhoeae in Riyadh, Saudi Arabia. Br. J. Vener. Dis., 57: 256-258.

Nayyar, K. C., Noble, R. C., Michel, M. F. et al. (1980) : Gonorrhoea in Rotterdam caused by penicillinase-producing gonococci. Br. J. Vener. Dis., 56: 244-248.

Percival, A., Rowlands, J., Corkill, J. E. et al. (1976) : Penicillinase-producing gonococci in Liverpool. Lancet, ii : 1379-1382.

Perine, P. L., Morton, R. S., Piot, P. et al. (1979) : Epidemiology and treatment of penicillinase-producing Neisseria gonorrhoeae. Sex. Trans. Dis., 6 (2) Supplement: 152-158.

Sparling, P. F., Biswas, G., Graves, J. et al. (1981) : Plasmids of the gonococcus. In : Molecular biology, pathogenicity, and ecology of bacterial plasmids. (Levy, S. B., Clowes, R. C. \& Koenig, E. L., ed.). Plenum Press, New York. pp. 237-246.

Urabe, S., Yoshida, S. \& Mizuguchi, Y. (1983) : Epidemiology and treatment of gonorrhoea caused by penicillinase-producing strains of Neisseria gonorrhoeae in Fukuoka, Japan. Br. J. Vener. Dis., 59 : $37-40$.

World Health Organization (1976) : Neisseria gonorrhoeae producing penicillinase. Weekly Epidemiological Record, $51: 293-294$.

Yoshida, S., Urabe, S. \& Mizuguchi, Y. (1982) : Antibiotic sensitivity patterns of penicillinase-positive and penicillinase-negative strains of Neisseria gonorrhoeae isolated in Fukuoka, Japan. Br. J. Vener. Dis., $58: 305-307$. 
ペニシリナーゼ産生淋菌とペニシリナーゼ非産生淋菌の混合感染による淋疾の一例

吉田 真一 ${ }^{1} \cdot$ 占部 $\quad$ 慎二 ${ }^{2} \cdot$ 水口 $\quad$ 康雄 $^{1}$

1産業医科大学微生物学教室 2 占部医院

要旨：ペニシリナーゼ産生淋菌 (PPNG) は東京, 大阪, 福岡など各都市で prostitute を中心に 定着しており，分離される割合は淋菌の 10-15\%である。この報告の 23 才男性淋摩患者 から分離された淋菌は最初，迅速ヨード法によりペニシリナーゼ産生が陰性であったので non-PPNG 株によるものと思われた。しかし 7 日間のアンピシリン服用によって症状が 改善せず再度分離した淋菌は，迅速ヨード法でペニシリナーゼ産生が陽性となった．患者 は治療中の再感染を否定しているので, 最初 non-PPNG 株に混じっていた少数の PPNG 株がアンピシリン治療により優位となって, 迅速ヨ一ド法が陰性から陽性に変ったと考え られる，病原菌の複合感染が最近問題となっているが，淋疾においてもこのような複合感 染がみられるので治療上注意を要すると思われた。

J. UOEH（産業医大誌），6（1）：87-90(1984) 